\title{
Antidiabetic, Antihyperlipidemic, Antioxidant Property of Cordia obliqua on Streptozotocin Induced Diabetic Rats
}

\author{
Prakash Ramakrishnan*, Dhivya Ramadoss, Priyadarshini Muthulingam, Ramya Nedunchezhian, Karthick Krishnamoorthy \\ Department of Pharmacology, KK College of Pharmacy, Gerugambakkam, Chennai 600128, Tamil Nadu, INDIA.
}

\begin{abstract}
Objective: The main objective is to investigate the antidiabetic, antihyperlipidemic and antioxidant activity of methanolic extract of Cordia obliqua (MECO) in streptozotocin- induced diabetic rats. Methods: Acute toxicity study of MECO was carried out in rat to determine its dose for further study. Oral glucose tolerance test was performed to evaluate MECO on elevated blood glucose levels. Diabetes was induced in rats by administration of streptozotocin (STZ) $(45 \mathrm{mg} / \mathrm{kg}$ ) and it was confirmed 3 days after induction. The methanolic extract of Cordia obliqua (MECO) was orally given to the diabetic rats up to 21 days and the blood glucose levels were estimated at the end of each week. On 21st day of the experiment, rats were sacrificed after the blood collection for the biochemical, antioxidants in kidney and pancreas was isolated for histopathological observation. Results: Acute toxicity MECO did not show toxicity and death up to a dose of $2000 \mathrm{mg} / \mathrm{kg}$ in rats. MECO $200 \mathrm{mg} / \mathrm{kg}$ and $400 \mathrm{mg} / \mathrm{kg}$ doses significantly $(P<0.005)$ reduced blood glucose levels in OGTT. Both the doses MECO treatment significantly $(P<0.005)$ increased the body weight, HDL by dose dependently when compared with STZ treated rats. Also, MECO treated rats significantly $(P<0.005)$ decreased the blood glucose,
\end{abstract}

SGOT, SGPT and ALP when compared with STZ treated rats. Normalized the lipid, antioxidant levels were reversed to near normal in diabetic rats treated with MECO. Conclusion: From the above results it was concluded that the plant extract having the ability of managing hyperglycemic and complication of diabetes in STZ induced diabetic rats. Hence this plant may be considered as one of the source for the isolation of new oral anti hypoglycemic agent

Key words: Cordia obliqua, Diabetes mellitus, Streptozotocin, Oral glucose tolerance, Hyperglycemic.

Correspondence :

Dr. Prakash Ramakrishnan, M.Pharm., Ph.D., Professor\& Head, Department of Pharmacology, KK College of Pharmacy, Gerugambakkam, Chennai, Tamil Nadu, INDIA.

Phone: 9940634459

Email: prakasheeba@rediffmail.com

DOI: 10.5530/jyp.2017.9.64

\section{INTRODUCTION}

Diabetes mellitus (DM) is a chronic metabolic disorder due to absolute or relative lack of insulin and characterized by hyperglycemia in the postprandial and or fasting state, mainly associated with ketosis and protein wasting in severe condition. ${ }^{1} \mathrm{DM}$ affects approximately $4 \%$ of the population worldwide and is expected to increase by $4.5 \%$ in 2025 . Diabetes is a chronic disease caused by inherited and or/ acquired deficiency in production insulin by the pancreas or by the ineffectiveness of the insulin produced. Hyperlipidemia and hyperglycemia are two important characters of diabetes mellitus. ${ }^{2}$ Free radicals derived from oxygen have been implicated in the pathophysiology of various diseases including diabetes mellitus. Moreover, also, evidence suggested that diabetes induced changes in the activities of antioxidant in various tissues. ${ }^{3}$ Oxidative stress is involved in the development and progression of various complications such as atherosclerosis, diabetic nephropathy and neuropathy. Currently, the available therapy for diabetic includes insulin and various oral anti-diabetic agents include sulfonyl ureas, biguanide, thiazolidinedione, and a glucosidase inhibitors. ${ }^{4}$ These agents, however, have restricted usage due to several undesirable side effects and fail to significantly alter the course of diabetic complications. In Ayurvedic and Siddha medicines, there are a number of Indian medicinal plants which have found to be useful to successfully manage diabetes. Advantage of traditional medicinal plants is no or lesser adverse effects with multiple therapeutic actions due to the presence of different bioactive compounds. ${ }^{5}$

Cordia obliqua Wild is an important medicinal plant belonging to the family Boraginaceae. ${ }^{6}$ It is useful as an expectorant and effective in treating the diseases of the lungs. In the raw condition, they contain a gum which can be used beneficially in gonorrhea. ${ }^{7}$ Seeds are utilized as an antiinflammatory agent. ${ }^{8}$ The fruits are also useful in treating coughs, the diseases of the chest, and chronic fever. They lessen thirst and the scalding of the urine, remove pain from the joints and the burning of throat and are also effective in treating the diseases of the spleen. Fruits are used as a demulcent in southern Iran. ${ }^{9}$ The preliminary phytochemical analysis of MECO revealed presence of tannins, flavonoids, saponins and phenolic compounds. ${ }^{10}$ It is well known phytochemical constituents from this group were reported for many pharmacological actions including antidiabetes activity.

Moreover up to date literature research revealed that there is no scientific report on C. obliqua plant to supports its use in the treatment of diabetes. Hence, objective of the present study is to investigate Antidiabetic, Antihyperlipidemic and antioxidant potential of methanolic extract of Cordia obliqua in STZ induced diabetic rats.

\section{MATERIALS AND METHOD}

\section{Plant material and extract}

Cordia obliqua plants were collected from Chennai, Tamilnadu during 2016. The plant material were shade dried, powdered and extracted with water and methanol using soxhlet apparatus. The extracts was concentrated in rotary evaporator at $35-40^{\circ} \mathrm{C}$ under reduced pressure. The MECO was stored at $2-8^{\circ} \mathrm{C}$ until the completion of pharmacological studies and the yield of the extract was 15\% (w/w). 


\section{Preliminary Phytochemical screening ${ }^{11,12}$}

Several phytochemical tests were performed for testing various different chemical groups present in methanolic extracts.

\section{Experimental animals}

Wistar albino rats (180-220 gm) were used to assess anti-diabetic activity. The rats were kept and maintained under standard laboratory conditions. The animal were fed with standard laboratory diet and allowed to drink water ad libitium. The studies were carried out in accordance with the institutional ethical guidelines for the care of laboratory animals.

\section{Chemicals}

STZ and all other chemicals used in this study were analytically grade and procured from sigma Aldrich laboratory, Mumbai.

\section{Acute toxicity study}

Acute toxicity studies were performed according to the organization for economic co-operation and development (OCED 423). The MECO was administered orally to the rats at a dose of $2000 \mathrm{mg} / \mathrm{kg}$. After the rats were orally administered, they were observed individually during first hour and then every $6 \mathrm{~h}$, then up to $24 \mathrm{~h}$, for toxicity determination with special attention and for any physical signs of toxicity such as writhing, gasping, palpitation and mortality ${ }^{[13]}$.

\section{Oral glucose tolerance test}

The oral glucose tolerance test (OGTT) was performed in overnight fasted normal rats. Rats were divided into three groups $(n=6)$. Group I served as normal control and received orally distilled water $(5 \mathrm{ml} / \mathrm{kg})$ and groups II and III, received MECO orally at the doses of 200 and $400 \mathrm{mg} / \mathrm{kg}$ respectively. After these treatments all groups received glucose $(5 \mathrm{~g} / \mathrm{kg})$ orally. Blood was withdrawn from the tail vein just prior to and 30, 60, 120 and 240 min after the oral glucose administration. ${ }^{14}$ Blood glucose levels were measured using single touch glucometer (Accucheck, Roche Diagnostics, USA).

\section{Induction of experimental diabetes}

Diabetes was induced in overnight fasted rats by STZ $(45 \mathrm{mg} / \mathrm{kg}$, i.p) after dissolving in freshly prepared cold citrate buffer. ${ }^{15}$ STZ induce fatal hypoglycemia as a result of massive pancreatic insulin release, the rats were provided with 5\% dextrose solution after 6 hours of STZ administration for next 24 hours to prevent hypoglycemia. ${ }^{16}$ Diabetes was confirmed $72 \mathrm{~h}$ after induction by measurement of tail vein blood glucose levels with the glucose meter. Diabetic rats were kept for 14 days under standard laboratory condition for the stabilization of blood glucose level. ${ }^{17}$ After 14 days induction of diabetes, blood glucose was again determined and only animals with a blood glucose level greater than $300 \mathrm{mg} / \mathrm{dL}$ were selected for the study.

\section{Experimental design}

Rats were divided into five groups each consists of minimum of six animals.

\begin{tabular}{cl}
\hline Groupings & \multicolumn{1}{c}{ Treatment } \\
\hline 1 & Normal rats received CMC $(5 \mathrm{ml} / \mathrm{kg} .$, p.o. $)$ \\
2 & STZ-induced diabetic rats $(45 \mathrm{mg} / \mathrm{kg} .$, i.p $)$ \\
3 & STZ-induced diabetic rats with glibenclamide $(5 \mathrm{mg} / \mathrm{kg} .$, p.o. $)$ \\
4 & STZ-induced diabetic rats with $\mathrm{MECO}(200 \mathrm{mg} / \mathrm{kg}$. p.o. $)$ \\
5 & STZ-induced diabetic rats with MECO $(400 \mathrm{mg} / \mathrm{kg} .$, p.o. $)$ \\
\hline
\end{tabular}

The vehicle, MECO and glibenclamide were administered orally to the respective groups for 21 days. The fasting blood glucose level and weight were estimated on $0,7,14,21$ days periodically. At the end of the experimental period the blood was collected from all the animals through retro-orbital plexus and rats were sacrificed and pancreas was isolated after the blood collection for the estimation of biochemical parameters.

\section{Estimation of blood glucose and body weight}

The body weight and fasting blood glucose level was determined after 21 days of treatment with extracts and drug control. The blood was collected from the tip of the tail vein from the overnight fasted rats and the blood glucose was measured (using Gluco Chek glucose estimation kit) [Aspen diagnostic (P) Ltd. Delhi, India]. The results were expressed in terms of milligrams per deciliter (mg/dL) of blood. Body weight of all experimental animals was recorded using a digital weighing scale.

\section{Measurement of Biochemical parameters}

Estimation of serum cholesterol was carried out by Zlatkis method. ${ }^{18}$ Serum triglycerides were estimated by Foster and Dunn method ${ }^{19}$ and HDL-cholesterol was estimated by Burstein method. ${ }^{20}$ The VLDL cholesterol was calculated using the formula, TG/5 mg/dl. The serum LDL cholesterol was calculated by Friedwald formula. ${ }^{21}$ Plasma SGOT and SGPT activities were determined by Reitman and Frankel method. ${ }^{22}$ Activity of serum alkaline phosphatase (ALP) was determined by p-nitro phenyl phosphate method. ${ }^{23}$

\section{Estimation of antioxidant levels}

Kidneys was dissected out and washed immediately with ice cold saline to remove blood. The antioxidants such as TBARS, SOD, GPx, GSH and CAT were estimated. ${ }^{24}$

\section{Histopathological investigation}

The animals were sacrificed and pancreas was dissected out, washed in normal saline, for Histopathological studies. Pancreatic tissues were fixed in $10 \%$ formalin, dehydrated with $50 \%-100 \%$ ethanol solution, and embedded in paraffin. The sections of $5 \mu \mathrm{m}$ thick were cut and stained with hematoxyllin-eosin, then examined under light microscope.

\section{Statistical analysis}

All the data expressed as mean \pm SEM were analyzed by one-way analysis of variance (ANOVA), followed by Dunnett's test using Prism Graph Pad and values of $\mathrm{P}<0.05$ were considered as statistically significant.

\section{RESULTS}

\section{Phytochemical analysis}

Phytochemical analysis showed presence of flavonoids, phenolics, alkaloids, tannins and saponins.

\section{Acute toxicity study}

The oral administration of MECO treated rats upto the dose of $2000 \mathrm{mg} / \mathrm{kg}$ did not exhibit any signs of toxicity for 14 days. It indicates that MECO was nontoxic in rats up to an oral dose of $2000 \mathrm{mg} / \mathrm{kg}$ of body weight. Therefore, the biological evaluation was carried out using $1 / 10$ and $1 / 20$ dose of MECO i.e. $200 \mathrm{mg} / \mathrm{kg}$ and $400 \mathrm{mg} / \mathrm{kg}$ dose levels.

\section{Effect of MECO on OGTT}

Glucose challenge to normal rats increased blood glucose levels with maximum level at 60 minutes and returned to normal level at $240 \mathrm{~min}$. The MECO administration improved glucose tolerance significantly $(P<0.001$ and $P<0.001)$ at $30 \mathrm{~min}$ to $120 \mathrm{~min}$ compared to diabetic control animals. Glucose loading to normal rats (OGTT) increased serum glucose levels from $61.26 \pm 1.7$ to $174.66 \pm 5.8$ at $60 \mathrm{~min}$ and reduced to normal at $240 \mathrm{~min}$. In MECO treated rats improved glucose tolerance significantly $(\mathrm{P}<0.001)$ in a dose dependent manner (Figure 1$)$.

\section{Effects of MECO on body weight and blood glucose}

Typographical error such as Table 1 is not cited. The STZ treated rats produced marked hyperglycemia as significant $(\mathrm{P}<0.001)$ elevation 


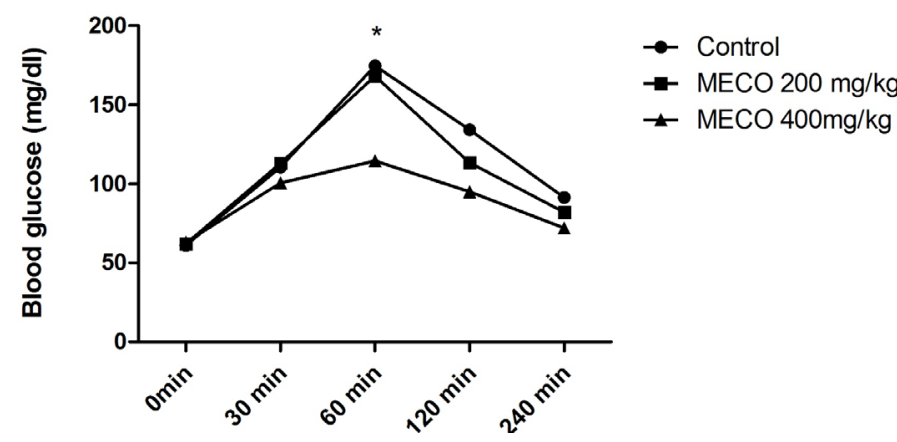

Figure 1: Effect of MECO on oral glucose tolerance test $(n=6) .{ }^{*} P<0.001$ compared to control rats.

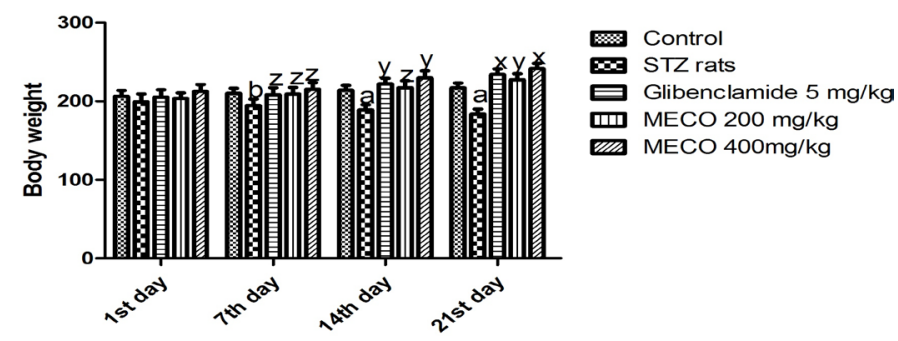

Figure 2: Effect of MECO on body weight in STZ induced diabetic rats $(n=6)$. $\mathrm{aP}<0.001, \mathrm{bP}<0.01$ and $\mathrm{cP}<0.05$ compared to control rats. $\mathrm{xP}<0.001, \mathrm{yP}<0.01$ and $z \mathrm{P}<0.05$ compared to control rats.
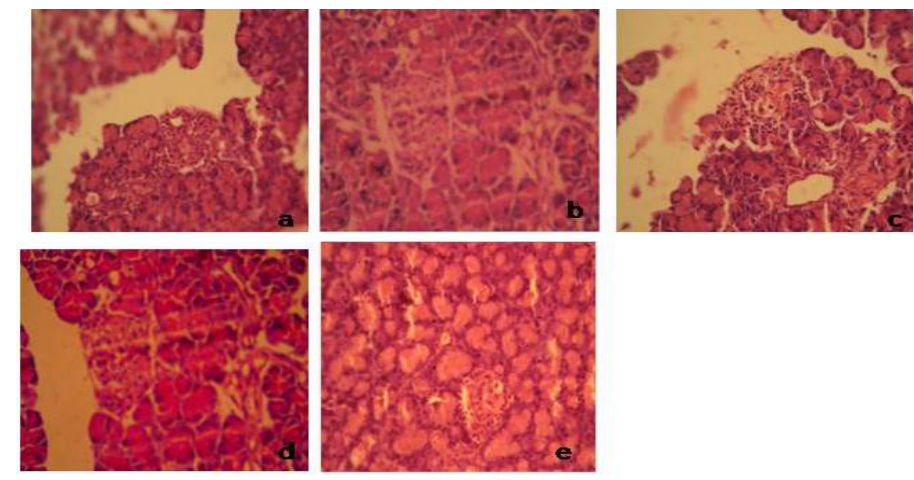

Figure 3: Histopathology of Pancreas a: Control b. Diabetic control indicates necrosis of $\beta$ cells, karyolysis and nuclear changes. c. Diabetic rats treated with Glibenclamide. ( $5 \mathrm{mg} / \mathrm{kg}$ ) showed prevented the destruction of $\beta$ cells. d. Diabetic rats treated with MECO $200 \mathrm{mg} / \mathrm{kg}$ showed minimal damage of $\beta$ cells e. Diabetic rats treated with MECO $400 \mathrm{mg} / \mathrm{kg}$ showed that prevented the $\beta$ cells almost near to standard glibenclamide treated rats.

in blood glucose level as compared to control rats. Administration of MECO in STZ induced diabetic rats at the dose of 200 and $400 \mathrm{mg} / \mathrm{kg}$ produced significant $(\mathrm{P}<0.001)$ and dose dependent fall in blood glucose levels when compared with STZ treated rats.

Normal rats were found to be stable in their body weight, but STZ treated rats, the body weight was significantly $(\mathrm{P}<0.001)$ decreased when compared to the normal rats. In STZ caused body weight reduction which was significantly reversed by MECO (200 and $400 \mathrm{mg} / \mathrm{kg}$ ) and glibenclamide $(5 \mathrm{mg} / \mathrm{kg}$ ) regained the body weight to near normal which is comparable with the normal rats (Figure 2).

\section{Effect of MECO on SGOT, SGPT and ALP levels}

The effects of MECO on the levels of SGOT, SGPT and ALP in control and diabetic rats are given in table 2. In STZ induced diabetic rats, all the biochemical parameters are significantly $(\mathrm{P}<0.001)$ increased when compared to control rats. The increase levels of SGOT, SGPT and ALP were significantly reduced after the administration of both doses of MECO (200 and $400 \mathrm{mg} / \mathrm{kg}$ ) by dose dependently and Glibenclamide $(5 \mathrm{mg} / \mathrm{kg})$ in compared with STZ induced diabetic rats.

\section{Effect of MECO on lipid profile}

In STZ rats, significant $(P<0.001)$ elevated level of total cholesterol, triglycerides, LDL and VLDL as well as decreased levels of HDL were observed, compared to normal rats. Both the doses of MECO significantly reduced elevated TC, TG, LDL and VLDL level in STZ induced diabetic rats. In MECO $400 \mathrm{mg} / \mathrm{kg}$ shows significant $(\mathrm{P}<0.05, \mathrm{P}<0.01$ and $\mathrm{P}<0.001)$ higher reduction of TC, TG, LDL and VLDL level in diabetic rats than MECO $200 \mathrm{mg} / \mathrm{kg}$. Moreover, HDL level was significantly $(\mathrm{P}<0.001)$ increased in diabetic rats treated with MECO both doses and Glibenclamide than diabetic control rats. The administration of MECO $400 \mathrm{mg} / \mathrm{kg}$ increases in HDL levels significantly $(\mathrm{P}<0.001)$ than MECO $200 \mathrm{mg} / \mathrm{kg}$ (Table 3).

\section{Effect of MECO on antioxidant levels}

There was a significant elevation in TBARS and reduction in SOD, CAT and GSH level in kidney of diabetic rats compared to control rats. The administration of MECO (200 and $400 \mathrm{mg} / \mathrm{kg}$ ) and glibenclamide significantly $(\mathrm{P}<0.001)$ reversed these changes to near normal levels (Table 4$)$.

\section{Histopathological investigation}

The control rats showed normal structure of $\beta$-cells in the islet of Langerhans on the endocrine portion and normal structure of acini in exocrine portion. In diabetic control rats nuclear changes, karyolysis and residue of destroyed cells were observed. Treatment of MECO $200 \mathrm{mg} / \mathrm{kg}$ to the diabetic rats showed minimal necrosis of $\beta$ cells when compared to diabetic control rats. At high dose of MECO $400 \mathrm{mg} / \mathrm{kg}$ treated diabetic rats prevented destruction of $\beta$ cells and size of islets of Langerhans towards normal when compared to diabetic control rats. The standard drug glibenclamide also prevented the destruction of $\beta$ cells and increases its number as well as size than diabetic rats (Figure 3).

\section{DISCUSSION}

The treatment of diabetes with medicines of plant origin that proved much safer than synthetic drugs is an integral part of many cultures throughout the world and gained importance in recent years. India has a rich history of using various potent herbs and herbal components for treating various diseases including diabetes. ${ }^{25}$

The present study is to investigate Antidiabetic, antihyperlipidemic and antioxidant potential of methanolic extract of Cordia obliqua in diabetic rats. In our study STZ was used to induce diabetes mellitus in rats. In STZ $(45 \mathrm{mg} / \mathrm{kg})$ treated rats were showed partially destructs the beta cells resulting in insufficient insulin secretion causing type 2 diabetes. ${ }^{26} \mathrm{It}$ is widely accepted animal model and reported to resemble human hyperglycemic non ketotic diabetes mellitus ${ }^{27}$ is often associated with kidney hypertrophy which may contribute to end stage renal damage, hepatotoxicity, oxidative stress and hypercholesterolemia. ${ }^{28,29}$

Acute toxicity study of the methanolic extract demonstrated that two different doses of Cordia obliqua were non-toxic throughout the experiment. The lethality was found to be zero in the groups of Cordia obliqua extract. Phytochemical investigation of MECO reveals the presences of flavanoids, saponins and tannins and phenolic compounds. It is well known that certain flavonoids exhibit hypoglycemic activity and pancreas beta cell regeneration ability. ${ }^{30}$ These principles phytoconstituents are known to be bioactive for the management of diabetes. In our present study the MECO produced significant antihyperglycemic activity at a dosage of $400 \mathrm{mg} / \mathrm{kg}$ when compared with STZ treated rats. 
Table 1: Effect of MECO on blood glucose in STZ induced diabetic rats $(n=6)$.

\begin{tabular}{ccccc}
\multirow{2}{*}{ Treatment } & \multicolumn{4}{c}{ Blood glucose level (mg/dl) } \\
\cline { 2 - 5 } & Day 1 & Day 7 & Day 14 & Day 21 \\
\hline Control & $62.50 \pm 2.83$ & $65.92 \pm 3.15$ & $72.87 \pm 1.26$ & $61.12 \pm 0.89$ \\
Diabetic control & $505.12 \pm 9.56^{\mathrm{a}}$ & $450.16 \pm 8.65^{\mathrm{a}}$ & $403.80 \pm 8.20^{\mathrm{a}}$ & $291.80 \pm 2.20^{\mathrm{a}}$ \\
Glibenclamide $5 \mathrm{mg} / \mathrm{kg}$ & $425.16 \pm 8.12$ & $265.67 \pm 12.23^{\mathrm{x}}$ & $199.77 \pm 1.70^{\mathrm{x}}$ & $97.10 \pm 2.80^{\mathrm{x}}$ \\
MECO 200 mg/kg & $498.17 \pm 10.12$ & $430.18 \pm 5.90^{1}$ & $306.89 \pm 3.50^{\mathrm{y}, 1}$ & $130.99 \pm 1.70^{\mathrm{x}, 2}$ \\
MECO 400 mg/kg & $490.16 \pm 9.15$ & $402.16 \pm 7.78^{1}$ & $229.85 \pm 2.20^{\mathrm{x}, 1}$ & $119.12 \pm 3.33^{\mathrm{x}}$ \\
\hline
\end{tabular}

${ }^{\mathrm{a}} \mathrm{P}<0.001$ diabetic control compared with control group. ${ }^{\mathrm{x}} \mathrm{P}<0.001,{ }^{\mathrm{y}} \mathrm{P}<0.01,{ }^{\mathrm{i}} \mathrm{P}<0.05 \mathrm{MECO} 200,400 \mathrm{mg} / \mathrm{kg}$ and glibenclamide $5 \mathrm{mg} / \mathrm{kg}$ compared with diabetic control. ${ }^{1} \mathrm{P}<0.001,{ }^{2} \mathrm{P}<0.01,{ }^{3} \mathrm{P}<0.05 \mathrm{MECO} 200,400 \mathrm{mg} / \mathrm{kg}$ compared with glibenclamide $5 \mathrm{mg} / \mathrm{kg}$.

Table 2: Effect of MECO on SGOT, SGPT, ALP in STZ induced diabetic rats $(n=6)$.

\begin{tabular}{cccc}
\hline \multirow{2}{*}{ Treatment } & \multicolumn{3}{c}{ Serum marker enzyme (U/L) } \\
\cline { 2 - 4 } & SGOT & SGPT & ALP \\
\hline Control & $62.09 \pm 0.87$ & $69.10 \pm 1.48$ & $122.57 \pm 0.60$ \\
Diabetic control & $153.21 \pm 9.80^{\mathrm{a}}$ & $134.98 \pm 11.59^{\mathrm{a}}$ & $243.68 \pm 12.32^{\mathrm{a}}$ \\
Glibenclamide $5 \mathrm{mg} / \mathrm{kg}$ & $73.21 \pm 6.10^{\mathrm{x}}$ & $72.18 \pm 7.68^{\mathrm{x}}$ & $128.18 \pm 12.89^{\mathrm{x}}$ \\
MECO $200 \mathrm{mg} / \mathrm{kg}$ & $94.93 \pm 8.35^{\mathrm{y}}$ & $85.10 \pm 12.25^{\mathrm{x}}$ & $145.87 \pm 9.67^{\mathrm{y}}$ \\
MECO $400 \mathrm{mg} / \mathrm{kg}$ & $80.89 \pm 7.92^{\mathrm{x}}$ & $79.10 \pm 11.30^{\mathrm{x}}$ & $130.10 \pm 8.87^{\mathrm{x}}$ \\
\hline
\end{tabular}

${ }^{\mathrm{a}} \mathrm{P}<0.001$ diabetic control compared with control group. ${ }^{\mathrm{x}} \mathrm{P}<0.001,{ }^{\mathrm{y}} \mathrm{P}<0.01,{ }^{\mathrm{i}} \mathrm{P}<0.05 \mathrm{MECO} 200$, $400 \mathrm{mg} / \mathrm{kg}$ and glibenclamide $5 \mathrm{mg} / \mathrm{kg}$ compared with diabetic control.

Table 3: Effect of MECO on Lipid profile in STZ induced diabetic rats $(n=6)$.

\begin{tabular}{cccccc}
\hline \multirow{2}{*}{ Treatment } & \multicolumn{5}{c}{ Serum lipid levels (mg/dL) } \\
\cline { 2 - 6 } & Total cholesterol & Triglycerides & HDL & LDL & VLDL \\
\hline Control & $148.78 \pm 1.79$ & $159.98 \pm 2.05$ & $81.25 \pm 0.95$ & $52.10 \pm 2.10$ & $35.61 \pm 0.31$ \\
Diabetic control & $251.10 \pm 12.10^{\mathrm{a}}$ & $281.25 \pm 10.95^{\mathrm{a}}$ & $25.01 \pm 11.29^{\mathrm{a}}$ & $262.10 \pm 12.8^{\mathrm{a}}$ & $113.10 \pm 8.57^{\mathrm{a}}$ \\
Glibenclamide $5 \mathrm{mg} / \mathrm{kg}$ & $160.87 \pm 5.57^{\mathrm{x}}$ & $186.12 \pm 6.52^{\mathrm{x}}$ & $50.90 \pm 5.25^{\mathrm{x}}$ & $85.12 \pm 9.35^{\mathrm{x}}$ & $56.87 \pm 9.80^{\mathrm{x}}$ \\
MECO $200 \mathrm{mg} / \mathrm{kg}$ & $195.86 \pm 8.20^{\mathrm{y}}$ & $238.95 \pm 7.90^{\mathrm{z}}$ & $35.17 \pm 6.81^{\mathrm{y}}$ & $112.89 \pm 8.90^{\mathrm{x}}$ & $77.85 \pm 6.93^{\mathrm{x}}$ \\
MECO $400 \mathrm{mg} / \mathrm{kg}$ & $165.32 \pm 11.39^{\mathrm{x}}$ & $227.87 \pm 12.50^{\mathrm{z}}$ & $42.81 \pm 8.95^{\mathrm{y}}$ & $92.18 \pm 11.50^{\mathrm{x}}$ & $62.89 \pm 5.90^{\mathrm{x}}$ \\
\hline
\end{tabular}

${ }^{a} \mathrm{P}<0.001$ diabetic control compared with control group. ${ }^{\mathrm{x}} \mathrm{P}<0.001,{ }^{\mathrm{P}} \mathrm{P}<0.01,{ }^{ } \mathrm{P}<0.05 \mathrm{MECO} 200,400 \mathrm{mg} / \mathrm{kg}$ and glibenclamide $5 \mathrm{mg} / \mathrm{kg}$ compared with diabetic control.

Table 4: Effect of MECO and Glibenclamide on Kidney antioxidant enzymes in STZ induced diabetic rats ( $n=6)$.

\begin{tabular}{|c|c|c|c|c|}
\hline Treatment & SOD (U/mg protein) & $\begin{array}{c}\text { CAT ( } \mu \text { mole } / \mathrm{L} \text { of } \mathrm{H}_{2} \mathrm{O}_{2} / \\
\mathrm{min} / \mathrm{mg} \text { protein) }\end{array}$ & $\begin{array}{c}\mathrm{GSH} \text { (mg of GSH/mg } \\
\text { protein) }\end{array}$ & $\begin{array}{l}\text { TBARS ( } \mu \text { M of MDA/ } \\
\mathrm{min} / \mathrm{mg} \text { protein) }\end{array}$ \\
\hline Control & $106.64 \pm 1.46$ & $25.57 \pm 0.61$ & $1.56 \pm 0.01$ & $165.58 \pm 1.22$ \\
\hline Diabetic control & $61.50 \pm 8.35^{\mathrm{a}}$ & $11.86 \pm 10.33^{a}$ & $0.467 \pm 1.21^{\mathrm{a}}$ & $328.28 \pm 6.04^{\mathrm{a}}$ \\
\hline Glibenclamide 5mg/kg & $91.63 \pm 6.93^{y}$ & $18.67 \pm 0.41^{y}$ & $0.86 \pm 0.12^{x}$ & $202.33 \pm 5.61^{x}$ \\
\hline MECO $200 \mathrm{mg} / \mathrm{kg}$ & $71.43 \pm 8.83$ & $13.25 \pm 0.25$ & $0.58 \pm 0.18$ & $269.07 \pm 6.50^{y}$ \\
\hline MECO 400 mg/kg & $85.44 \pm 11.62^{y}$ & $16.03 \pm 0.44$ & $0.73 \pm 0.26^{y}$ & $250.08 \pm 8.85^{y}$ \\
\hline
\end{tabular}

${ }^{a} \mathrm{P}<0.001$ diabetic control compared with control group. ${ }^{x} \mathrm{P}<0.001,{ }^{\mathrm{y}} \mathrm{P}<0.01,{ }^{ } \mathrm{P}<0.05 \mathrm{MECO} 200,400 \mathrm{mg} / \mathrm{kg}$ and glibenclamide $5 \mathrm{mg} /$ $\mathrm{kg}$ compared with diabetic control.

In diabetic patients, the main objective of the treatment is to lower blood glucose to near- normal levels. ${ }^{31}$ The oral glucose tolerance test confirmed blood glucose lowering activity of MECO. The onset of antihyperglycemic action was observed from $60 \mathrm{~min}$ of the treatment and a steady state increase in the action continued up to $120 \mathrm{~min}$. The MECO may be involved in enhancement of glucose utilization, so blood glucose levels were significantly decreased in glucose loaded rats. The decrease in body weight, increase in food and water intake was commonly observed in diabetes and it may be due to metabolic changes caused by lack or deficiency of insulin due to destruction of $\beta$ - cells. ${ }^{32}$ In STZ induced diabetic rats, drastic reduction in body weight changes observed might be the result of degradation or catabolism of structural proteins due to 
unavailability of carbohydrate for the energy metabolism and increased muscle wasting in diabetes. ${ }^{33,34}$ Previous reports supports for our study reports diabetic rats significantly reduced the body weight when compared to normal rats and body weight was significantly increased in diabetic rats treated with MECO showed the blood glucose stabilization effect which in turn prevents the loss of body weight.

Liver is the vital organ of metabolism, detoxification, storage and excretion of xenobiotics and their metabolites. SGOT, SGPT and ALP are reliable markers of liver function. The liver was necrotized in STZ-induced diabetic rats. Therefore an increase in the activities of SGOT, SGPT and ALP in plasma might be mainly due to the leakage of these enzymes from the liver cytosol into the blood stream which gives an indication of the hepatotoxic effect of STZ. ${ }^{35}$ Treatment of the diabetic rats with the MECO caused reduction in the activity of these enzymes in plasma compared to the diabetic control group and consequently alleviated liver damage caused by STZ-induced diabetes.

Lower-extremely arterial disease, coronary heart disease and cerebrovascular disease are frequently vascular complications in diabetes. The atherogenic process occurrences in vascular disease are proceeding at a more rapid rate in diabetic than in non-diabetic subjects. ${ }^{36}$ The vascular disease accounts for more than $60 \%$ of the morbidity of diabetes that includes both micro and macrovascular disease, and is common in both type of diabetic patients. ${ }^{37}$ In this study, administration of MECO significantly reduced elevated total cholesterol, triglycerides, VLDL and LDL levels in diabetic rats. Also, increased level of HDL was observed in diabetic rats treated with $400 \mathrm{mg} / \mathrm{kg}$ dose of MECO and glibenclamide compared to diabetic control rats. This action of MECO supports its lipid lowering activity in diabetic condition and therefore it helps to prevents diabetic associated complication.

Increased free radical generation and oxidative stress are hypothesized to play an important role in the pathogenesis of diabetes and it's late to play an important role in the pathogenesis of diabetes and its late complications. Several evidences suggest that STZ induces oxidative stress. ${ }^{38}$ The generation of superoxide anion radicals by glucose oxidation and its dismutation to hydrogen peroxide, which if not scavenged by CAT or GPx, leads to the formation of reactive hydroxide radicals. ${ }^{39,40}$ Also, superoxide anion radicals react with nitric acid to form reactive peroxynitrite radicals. ${ }^{41,42}$ Free radicals are formed disproportionately in diabetes by glucose auto oxidation, thus result in consumption of antioxidant defenses which lead to disruption of cellular function and oxidative damage to membranes and enhance susceptibility to lipid peroxidation. ${ }^{43} \beta$-cell is particularly sensitive to damage by free radicals because of their low level of free radical scavenging enzymes that leads to hyper glycaemic condition. Reduced oxidative stress due to reduced hyperglycemic status in diabetic condition had been observed in experimental animals following the administration of certain natural compounds. ${ }^{44}$ Administration of MECO significantly reduced TBARS and increased SOD, CAT, GPx and reduced GSH levels in diabetic rats. The action of the MECO to restore the altered antioxidant enzymes in STZ-induced diabetic rats indicates its free radical scavenging potential and hence it has the ability to prevent diabetic associated complications. The Histopathological investigation clearly supported that MECO has prevent pancreatic $\beta$-cell damage, islets of Langerhans size and numbers it may leads to increase production of insulin.

\section{CONCLUSION}

The present study clearly concluded that Methanol extract of Cordia obliqua possess ability to control blood glucose in diabetes. It's antihyperlipidemic and free radical scavenging property has potential to prevent diabetic associated complications. Our current investigation supports the traditional use of Cordia obliqua in the treatment of diabetes.

\section{ACKNOWLEDGEMENT}

We are grateful to thank the Principal, KK College of Pharmacy., Chennai, Tamil Nadu, India, for providing research facilities.

\section{CONFLICT OF INTEREST}

The authors declare no conflict of interest.

\section{ABBREVIATIONS USED}

DM: Diabetes Mellitus; MECO: Methanolic extract of Cordia obliqua; OECD: Organization for economic co-operation and development; OGTT: Oral glucose tolerance test; STZ: Streptozotocin; mg/dL: Milligrams per deciliter.

\section{REFERENCES}

1. Daisy P. A novel steroid from Elephanthopusscaber $L$. An ethanomedicin plant with antidiabeticactivity. Phytomedicine. 2009;16(2):252-7. https://doi. org/10.1016/j.phymed.2008.06.001; PMid:18693100

2. Gipsen WH, Biessels GJ. Cognition and synaptic plasticity in diabetes mellitus Trends Neurosci. 2000;23(11):542-9. https://doi.org/10.1016/S0166-2236(00)01656-8.

3. Ahmed RG. The Physiological and biochemical effects of diabetes on the balance between oxidative stress and oxidative defense system. Med J Islamic World. Acad Sci. 2005;15:31-42

4. Kim SH, Hyun SH, choung SY. Antidiabetic effect of cinnamon extract on blood glucose in db/db mice. J Ethnopharmacol. 2006;104(1):119-23. https://doi. org/10.1016/j.jep.2005.08.059; PMid:16213119.

5. American diabetes association: Diagnosis and classification of diabetes mellitus Diabetes care. 2005;28(1):S37-42. PMid:15618111.

6. Ravikumar S, Uthiraselvam M, Natarajan K, Babuselvam M, Rajabudeen E. Studies on the Pharmacognistic properties of Cordia obliqua Willd. Int $\mathrm{J}$ of Pharma Res And Dev. 2011;2(3):185-6.

7. Parmar C, Kaushal MK. Cordia obliqua. In: Wild Fruits. Kalyani Publishers, New Delhi, India. 1982;19-22.

8. Agnihotri VK, Srivastava SD, Srivastava SK, Pitre S, Rusia K. Ind J Pharm Sci. $1987 ; 49(2): 66-9$

9. Kirtikar KR, Basu BD, Indian medicinal plants. (Lalitmohan Basu, Allahabad, India) 1935;1(2):785-88.

10. Arinathan V, Mohan VR, De Britto JA, Murugan C. Wild edibles used by Palliyars of the Western Ghats, Tamil Nadu. India

11. Harbone JB. Phytochemical method. Chapman Hall; 1988:117-9

12. Agrawal OP. Advanced practical organic chemistry. Goel Publishing House; 2000:43-59.

13. Petchi RR, Vijaya C, Parasuraman S. Antidiabetic activity of polyherbal formulation in streptozotocin - nicotinamide induced diabetic wistar rats. J Tradit Complement Med. 2014;4(2):108-17. https://doi.org/10.4103/2225-4110.126174 PMid:24860734 PMCid:PMC4003700.

14. Soltani N, Keshavarz M, Dehpour AR. Effect of oral magnesium sulfate administration on blood pressure and lipid profile in streptozotocin diabetic rat. Eur J Pharmacol. 2007;560(2):201-5. https://doi.org/10.1016/j.ejphar.2006.12.020; PMid:17292879.

15. Upwar NK, Patel R, Waseem N. hypoglycemic effect of methanolic extract of Berberisaristata DC stem on normal and STZ induced diabetic rats. IJP. $2011 ; 3(1): 222-4$

16. Tanko Y, Yerima M, Mahdi MA, Yaro AH, Musa KY, Mohammed A. Hypoglycemic activity of methanolic stem bark of Adansonniadigitata extract on blood glucose levels of streptozotocin-induced diabetic Wistar rats. Inter J Appl Res Nat Prod. 2008;1(2):32-6

17. Vogel HG. Drug Discovery and Evaluation: Pharmacological assays. 2nd ed. Berlin Heidelberg: Springer-Verlag. 2002:951. https://doi.org/10.1007/3-540-29837-1.

18. Zlatkis A, Zak B, Boyle AJ. A new method for the direct determination of serum cholesterol. J Lab Clin Med. 1953;41:486-49 PMid:13035283

19. Foster JB, Dunn RT: Stable reagents for determination of serum triglycerides by colorimetric Hantzsch condensation method. Clin Chem. 1973;19(3):338-40. PMid:4347544

20. Burstein M, Scholnichk HR, Morin R. Rapid method for the isolation of lipoproteins from human serum by precipitation with polyanions. J Lipid Res. 1970;11(6):583-95. PMid:4100998.

21. Friedwald WT, Levy RI, Fredrickson DS. Estimation of the concentration of LDLcholesterol in plasma without the use of the preparative Ultracentrifuge. Clin Chem. 1972;18(6):499-502.

22. Reitman S, Frankel S. Colorimetric method for the determination of serum glutamic oxaloacetic acid and glutamic pyruvic transaminases. Am J Clin Pathol. 1957;28(1):56-63. https://doi.org/10.1093/ajcp/28.1.56 ; PMid:13458125. 
23. Bessey OA, Lowry OH, Brock MJ. A method for the determination of alkaline phosphatase with five cubic millimeters of serum. J Biol Chem. 1946;164:321-9. PMid:20989492

24. Murugan P, Pari L. Antioxidant effect of Tetrahydrocurcumin in steptozotocinnicotinamide induced diabetic rats. Life Sci. 2006;79(18):1720-8. https://doi. org/10.1016/j.Ifs.2006.06.001; PMid:16806281.

25. Yeh GY, Eisenberg DM, Kaptchuk TJ, Phillips RS. Systematic review of herbs and dietary supplements for glycemic control in diabetes. Diabetes Care. 2003;26(4):1277-94. https://doi.org/10.2337/diacare.26.4.1277; PMid:12663610.

26. Gomes A, Vedasiromoni JR, Das M, Sharma RM, Ganguly DK: Antihyperglycemic effect of black tea (Camellia sinensis) in rat. J Ethnopharmacol. 2001;27:243-75.

27. Weir GC, Clore ET, Zmachiroski CJ, Bonner-Weir S. Islet secretion in a new experiment model for non-insulin dependent diabetes. Diabetes. 1981;30(7): 590-5. https://doi.org/10.2337/diab.30.7.590 ; PMid:6114005.

28. Heidland A, Ling H, Vamvakas S, Paczek L. Impaired proteolytic activity as a potential cause of progressive renal disease. Miner Electrolyte Metab. 1996;22(1-3):157-61. PMid:8676810.

29. Rabkin R, Schechter $P$, Shi JD, Boner G. Protein turnover in the hypertrophy in kidney. Miner Electrolyte Metab. 1996;22:153-6. PMid:8676809.

30. Singh SK, Kesari AN, Gupta RK, Jaiswal D, Watal G. Assessment of antidiabetic potential of Cynodondactylon extract in streptozotocin diabetic rats. Ethnopharmacol. 2007;114(2):174-9. https://doi.org/10.1016/j.jep.2007.07.039; PMid:17889469

31. American diabetes association. Standard of medical care for patients with diabetes mellitus. Diabetes care. 1998;21:22-31. https://doi.org/10.2337/ diacare.21.1.s23.

32. Ahmed D, Kumar V, Verma A, Shukla GS, Sharma M. Antidiabetic, Antioxidant, Antihyperlipidemic effect of extract of Euryale ferox salisb. With enhanced histopathology of pancreas, liver and kidney in STZ induced diabetic rats. Springer plus. 2015;4(1):315. https://doi.org/10.1186/s40064-015-1059-7; PMid:26155454 PMCid:PMC4489967.

33. Rodriguez T, Alvarez B, Busquets S, Carbo N, Lopez-Soriano FJ, Argiles JM. The increased skeletal muscle protein turnover of the streptozocin diabetic rats is associated with high concentrations of branched-chain amino acids. Bio chem Mol Med. 1997;61(1):87-94. https://doi.org/10.1006/bmme.1997.2585.

34. Pepto MT. Migliorini RH, Goldberg AL. Kettelhut IC. Role of different proteolytic pathways in degradation of muscle protein from steptozotocin-diabetic rats. Am J Physiol. 1996;271(2):E340-7.

35. Kasetti RB, Rajasekhar MD, Kondeti VK, Fatima SS, Kumar EGT, Swapna S, et al. Antihyperglycemic and antihyperlipidemic activities of methanol: water (4:1) fraction isolated from aqueous extract of Syzygiumalternifolium seeds in streptozotocin induced diabetic rats. Food chem Toxicol. 2010;48(4):1078-84. https://doi.org/10.1016/j.fct.2010.01.029; PMid:20122979.

36. Maser RE, Wolfson SK Jr, Ellis D, Stein EA, Drash AL, Becker DJ, et al Cardiovascular disease and arterial calcification in insulin-dependent diabetes mellitus: Interrelations and risk factor profiles. Pittsburgh epidemiology of diabetic complication study-V. Arterioscler Thromb. 1991;11(4):958-65. https:// doi.org/10.1161/01.ATV.11.4.958; PMid:2065046.

37. Barakat HA, Vadlamudi S, MacLean P, MacDonald K, Pories WJ. Lipoprotein metabolism in non-insulin-dependent diabetes mellitus. J Nutriochem. 1996;7:586-65. https://doi.org/10.1016/s0955-2863(96)00117-9.

38. Wright JR Jr, Abraham C, Dickson BC, Yang H, Morrison CM. (1999). Streptozotocin dose-response curve in tilapia, a glucose-responsive teleost sh. Gen Comp Endocrinol. 1999;114:431-40. https://doi.org/10.1006/gcen.1999.7269; PMid:10336831.

39. Jiang ZY, Woollard Ac, Wolff SP. Hydrogenproxide production during experimental protein glycation. FEBS Lett. 1990;268(1):69-71. https://doi.org/10.1016/00145793(90)80974-N.

40. Wolff SP, Dean RT. Glucose autoxidation and protein modification. The potential role of 'autoxidative glycosylation' in diabetes. Bio chem J. 1987;245(1):243-50. https://doi.org/10.1042/bj2450243; PMid:3117042 PMCid:PMC1148106.

41. Halliwell B, Gutteridge JM. Role of free radicals and catalytic metal ions in human disease: an overview. Method enzymon. 1990;186:1-85. https://doi. org/10.1016/0076-6879(90)86093-B.

42. Hogg N, Kalyanaraman B, Joseph J, Struck A, Parthasarathy S. Inhibition of low -density lipoprotein oxidation by nitric oxide. Potential role in atherogenesis. FEBS Lett. 1993;334(2):170-4. https://doi.org/10.1016/0014-5793(93)81706-6.

43. Baynes JW. Role of oxidative stress in development of complications in diabetes. Diabetes. 1991;40(4):405-12. https://doi.org/10.2337/diab.40.4.405; PMid:2010041.

44. Sanders RA, Rauscher FM, Watkins JB. Effect of quercetin on Streptozotocininduced diabetic rats. J Bio chem. Mol. Toxicology. 2001;15(3):143-9. https://doi. org/10.1002/jbt. $11 ;$ PMid:11424224.

Article History: Submission Date : 03-02-2017; Revised Date : 14-02-2017; Acceptance Date : 07-03-2017.

Cite this article: Ramakrishnan P, Ramadoss D, Muthulingam P, Nedunchezhian R, Krishnamoorthy K. Antidiabetic, Antihyperlipidemic, Antioxidant Property of Cordia obliqua on Streptozotocin Induced Diabetic Rats. JYoung Pharm. 2017;9(3):321-6. 